\section{Clinical implications}

- HIV infected blood may still be transfused in Africa because of lack of access to HIV testing, lack of adequate laboratory quality control, and from donors being in the seroconversion period

- Donor deferral has not been thought feasible in Africa because heterosexual transmission accounts for most cases of HIV infection, making risk groups difficult to identify

- Not everyone is at equal risk for HIV infection; in Abidjan, Côte d'Ivoire, important risk factors for HIV infection among male blood donors were prostitute contact and age

- Behavioural characteristics identified a large proportion of donors who were most likely to be HIV infected; a history of prostitute contact in the past five years identified $73 \%$ of $\mathrm{HIV}$ infected donors while being present in $31 \%$ of all donors

- Excluding donors based on behavioural characteristics of those most at risk of HIV infection is feasible in Abidjan. Donor deferral merits evaluation as an intervention to improve blood safety in developing countries
Although the priority must remain to extend HIV testing to all units of blood transfused, donor deferral merits investigation in resource poor areas. Exclusion criteria may differ between societies, and this study should be repeated in other developing countries. Additional requirements for improved blood safety in the developing world are country specific guidelines and supervision of transfusion practices and more emphasis on eliminating all but lifesaving transfusions.

1 Doll LS, Petersen LR, White CR, Ward JW, HIV Blood Donor Study Group. Human immunodeficiency virus type 1 infected blood donors: behavioral characteristics and reasons for donation. Transfusion 1991;31:704-9.

2 Mann J, Tarantola DJM, Netter TW, eds. Blood safety and blood products. In: $A I D S$ in the world. Cambridge, Mass: Harvard University Press, 1992:421-37.

3 Chin J, Mann JM. Global surveillance and forecasting of AIDS. Bull World Health Organ 1989;67:1-7.

4 Greenberg AE, Nguyen-Dinh P, Mann JM, Kabote N, Colebunders RL, Francis $\mathrm{H}$, et al. The association between malaria, blood transfusions and HIV seropositivity in a pediatric population in Kinshasa, Zaire. $J A M A$ 1988;259:545-9.

5 Lackriz EM, Campbell CC, Ruebush TK II, Hightower AW, Wakube W, Steketee RW, et al. Effect of blood transfusion on survival among children in a Kenyan hospital. Lancet 1992;340:524-8.

6 Jager $\mathrm{H}$, Jersiid $\mathrm{C}$, Emmanuel JC. Safe blood transfusions in Africa. AIDS 1991; 5:S163-8.

7 N'tita I, Mulanga K, Dulat C, Lusamba D, Rehle H, Korte R, et al. Risk of transfusion-associated HIV infection in Kinshasa, Zaire. AIDS 1991;5: 437-41.

serological testing cannot identify donors in the seroconversion period; exclusion on risk factors may be the only way to deal with what could be a common finding in areas of high incidence of HIV infection.' Lastly, laboratory errors are inevitable, and false negative results are less likely when HIV prevalence in the donor pool is low.

The absence of donor exclusion before the introduction of HIV antibody testing may in part explain the greater number of HIV infected transfusion recipients in France than in other European countries. ${ }^{14}$ Even with blood screening, the current risk of transfusion transmitted HIV infection in Abidjan-and presumably in other African cities with high HIV infection incidence and prevalence-exceeds that which existed in industralised countries at the beginning of the HIV epidemic. ${ }^{9}$
MRC Environmental

Epidemiology Unit,

University of

Southampton,

Southampton General

Hospital, Southampton

SO9 4XY

C Osmond, statistician

D J P Barker, director

P D Winter, computing manager

C H D Fall, paediatrician

S J Simmonds, research

assistant

Correspondence to:

Professor Barker.

$B M 7$ 1993;307:1519-24

\title{
Early growth and death from cardiovascular disease in women
}

\section{Osmond, D J P Barker, P D Winter, C H D Fall, S J Simmonds}

\begin{abstract}
Objective-To determine whether the link suggested between growth in utero and during infancy and death from cardiovascular disease in men is also present in women.

Design-Follow up study of women and men whose birth weight and weight at 1 year of age had been recorded.

Setting-Hertfordshire, England.

Subjects-5585 women and 10141 men born during 1911-30.

Main outcome measures-Standardised mortality ratios for cardiovascular disease.

Results-Among women and men death rates from cardiovascular disease fell progressively between the low and high birth weights groups $\left(\chi^{2}=4.3, p=0.04\right.$ for women, $\chi^{2}=8.5, p<0.005$ for men). Cardiovascular deaths in men but not women were also strongly related to weight at 1 year, falling progressively between the low and high weight groups $\left(\chi^{2}=27.5, p<0.0001\right)$. The highest cardiovascular death rates in women were among those with below average birth weight but above average weight at 1 year. In men the highest rates were among those with below average birth weight and below average weight at 1 year.

Conclusion-Relations between cardiovascular
\end{abstract}

disease and birth weight are similar in men and women. In men cardiovascular disease is also related to weight gain in infancy.

\section{Introduction}

The first direct evidence that coronary heart disease may originate in utero and during infancy came from a study of men born in Hertfordshire, England.' The birth weight and weight at 1 year of all babies born in the county since 1911 had been recorded. Among 5654 men born during 1911-30, death rates from coronary heart disease fell progressively between those with the lowest and highest weights at 1 year. There were similar, though less strong, trends with birth weight. A study of 1586 men born in Sheffield similarly showed that death rates from cardiovascular disease fell progressively between those who had low and high birth weight. ${ }^{2}$ This trend did not depend on differences in the length of gestation and therefore reflected differences in fetal growth rates.

Subsequent studies suggested that growth in utero and during infancy and the method of infant feeding were linked to the main risk factors for cardiovascular disease. Men and women who had had reduced rates of fetal growth or low weights at 1 year had raised prevalences of hypertension and non-insulin dependent 
diabetes, raised serum cholesterol and plasma fibrinogen concentrations, and a tendency to store fat centrally. ${ }^{3}$ Men who were breast fed beyond 1 year of age had raised serum cholesterol concentrations.

These findings support the hypothesis that cardiovascular disease originates from impaired development in utero and during infancy. This is known as programming, whereby adverse influences acting during sensitive periods of early life permanently change the structure and physiology of the body's tissues. The hypothesis proposes that fetal undernutrition leads to persisting changes in the levels of secretion of hormones, including insulin and growth hormone, and in the sensitivity of tissues to them. ${ }^{4}$ These changes have important long term effects on metabolism.

The effect of early growth and infant feeding on cardiovascular disease in women is unknown. In Britain women are more difficult to trace than men because of their change of name at marriage, and follow up of women born in Hertfordshire has been completed only recently. We present here the findings for 5585 women who were born during 1923-30. We also present findings for an extended cohort of men, who now number 10141 .

\section{Subjects and methods}

As previously described all births in Hertfordshire from 1911 onwards were notified by the attending midwife. ${ }^{1}$ Health visitors saw the babies periodically throughout infancy and recorded the method of feeding. At 1 year of age the babies were weighed. Our previous analysis was of boys born in six of the 12 districts in the county. We present here findings for five additional districts, Berkhamsted, Cheshunt (within Edmonton), Hemel Hempstead, Hitchin, and Watford. The records for one district, St Albans, have not been found. Using the NHS central register at Southport, we traced boys born during 1911-30 and girls born during 1923-30. We could not trace girls born before 1923 because the new names of many of those who married could not be determined.

We excluded twins and triplets and singletons who died during childhood, leaving 23094 boys and 13850 girls. Birth weight and weight at 1 year, and sufficient identification data for tracing were recorded for 12815 boys and 9323 girls. Weights were measured in pounds $(2 \cdot 2$ pounds $=1 \mathrm{~kg})$ and were often rounded to the nearest half pound or pound. In our analyses we therefore preserved the original units. We traced $10141(79 \%)$ of the boys and $5585(60 \%)$ of the girls; 2472 of the boys and 690 of the girls had died aged 20-74 between 1 January 1951 and 31 December 1992. The average birth weight and weight at 1 year of men who were not traced were $0 \cdot 1$ and $0 \cdot 2$ pounds less than those of men who were traced. The averages for women who were not traced were the same. Cardiovascular disease was defined by the International Classification of Diseases (9th revision) codes 390-459, coronary heart disease by the codes $410-414$, and lung cancer by the codes 162-164. The social class of all except 65 men and 73 women who had died was derived from the occupation recorded on the death certificate.

\section{STATISTICAL METHODS}

We analysed cause of death in relation to birth weight, weight at 1 year, and infant feeding. The numbers of deaths were compared with those expected from national rates for women and men of corresponding age and year of birth. ${ }^{5}$ Death rates were expressed as standardised mortality ratios, with the national average as 100 . Tests for trend were based on the corresponding log-linear model. We used the same infant feeding groups, and groups of birth weight and weight at 1 year as in our previous analysis. ${ }^{16}$

\section{Results}

Of the 690 deaths among women, 183 were due to cardiovascular disease, of which 88 were due to coronary heart disease, 37 to stroke, and 58 to other circulatory disease. A total of 1172 of the 2472 deaths among men were due to cardiovascular disease, of which 853 were due to coronary heart disease, 121 to stroke, and 198 to other circulatory disease. The overall death rates from cardiovascular disease were below the national average, the standardised mortality ratios being 70 for women and 77 for men.

The average birth weight was 7.5 pounds $(3.4 \mathrm{~kg})$ for women and 7.8 pounds $(3.6 \mathrm{~kg})$ for men. Average weights at 1 year were 21.4 pounds $(9.7 \mathrm{~kg}$ ) and 22.5 pounds $(10.2 \mathrm{~kg})$. Tables I and II show standardised mortality ratios by birth weight and weight at 1 year and use the same groupings as in our previous analysis. ${ }^{1}$ Among women (table I) standardised mortality ratios for cardiovascular disease fell with increasing birth weight $\left(\chi^{2}=4 \cdot 3, p=0.04\right)$. The trend in death from coronary heart disease with birth weight was similar, although this was based on fewer deaths and was not significant. There was no trend in non-cardiovascular causes of death, though women with birth weights of 5.5 pounds or less had raised death rates, (standardised mortality ratio 120, 95\% confidence interval 85 to 165 ). No trend was found with lung cancer. There were no trends with weight at 1 year for cardiovascular disease, coronary heart disease, non-cardiovascular causes of death, or lung cancer.

TABLE I-Standardised mortality ratios among women according to birth weight and weight at 1 year

\begin{tabular}{|c|c|c|c|c|c|c|c|c|c|c|c|c|c|c|c|}
\hline \multirow[b]{3}{*}{ Weight (pounds) } & \multicolumn{15}{|c|}{ Cause of death } \\
\hline & \multicolumn{3}{|c|}{ Coronary heart disease } & \multicolumn{3}{|c|}{ All cardiovascular disease } & \multicolumn{3}{|c|}{ All other causes } & \multicolumn{3}{|c|}{ Lung cancer } & \multicolumn{3}{|c|}{ All causes } \\
\hline & $\begin{array}{c}\text { Standardised } \\
\text { mortality } \\
\text { ratio }\end{array}$ & $\begin{array}{c}95 \% \\
\text { Confidence } \\
\text { interval }\end{array}$ & $\begin{array}{l}\text { No of } \\
\text { deaths }\end{array}$ & $\begin{array}{l}\text { Standardised } \\
\text { mortality } \\
\text { ratio }\end{array}$ & $\begin{array}{c}95 \% \\
\text { Confidence } \\
\text { interval }\end{array}$ & $\begin{array}{l}\text { No of } \\
\text { deaths }\end{array}$ & $\begin{array}{l}\text { Standardised } \\
\text { mortality } \\
\text { ratio }\end{array}$ & $\begin{array}{c}95 \% \\
\text { Confidence } \\
\text { interval }\end{array}$ & $\begin{array}{l}\text { No of } \\
\text { deaths }\end{array}$ & $\begin{array}{c}\text { Standardised } \\
\text { mortality } \\
\text { ratio }\end{array}$ & $\begin{array}{c}95 \% \\
\text { Confidence } \\
\text { interval }\end{array}$ & $\begin{array}{l}\text { No of } \\
\text { deaths }\end{array}$ & $\begin{array}{l}\text { Standardised } \\
\text { mortality } \\
\text { ratio }\end{array}$ & $\begin{array}{c}95 \% \\
\text { Confidence } \\
\text { interval }\end{array}$ & $\begin{array}{l}\text { No of } \\
\text { deaths }\end{array}$ \\
\hline \multicolumn{16}{|l|}{ At birth: } \\
\hline$\leqslant 5.5(n=307)$ & 83 & 31 to 181 & 6 & 80 & 40 to 144 & 11 & 120 & 85 to 165 & 38 & 92 & 19 to 274 & 3 & 108 & 80 to 143 & 49 \\
\hline $6-6 \cdot 5(n=1068)$ & 72 & 43 to 112 & 19 & 82 & 59 to 111 & 41 & 72 & 58 to 90 & 83 & 67 & 29 to 132 & 8 & 75 & 63 to 90 & 124 \\
\hline $7-7.5(n-1956)$ & 67 & 46 to 94 & 32 & 76 & 59 to 96 & 69 & 85 & 73 to 99 & 179 & 88 & 53 to 137 & 19 & 83 & 73 to 94 & 248 \\
\hline $8-8.5(n=1532)$ & 59 & 37 to 88 & 23 & 63 & 46 to 83 & 46 & 84 & 71 to 100 & 141 & 58 & 28 to 106 & 10 & 78 & 67 to 90 & 187 \\
\hline $9-9.5(\mathrm{n}=551)$ & 43 & 16 to 93 & 6 & 46 & 24 to 80 & 12 & 87 & 65 to 114 & 52 & 112 & 45 to 233 & 7 & 74 & 57 to 95 & 64 \\
\hline$\geqslant 10(n=171)$ & 49 & 6 to 176 & 2 & 51 & 14 to 131 & 4 & 78 & 43 to 131 & 14 & 0 & 0 to 205 & 0 & 70 & 42 to 111 & 18 \\
\hline At 1 year: & & & & & & & & & & & & & & & \\
\hline$\leqslant 18(n=617)$ & 91 & 50 to 153 & 14 & 72 & 45 to 110 & 21 & 107 & 84 to 135 & 71 & 87 & 32 to 189 & 6 & 96 & 78 to 118 & 92 \\
\hline $19-20(n=1486)$ & 54 & 33 to 83 & 20 & 70 & 52 to 93 & 49 & 80 & 67 to 95 & 128 & 78 & 42 to 134 & 13 & 77 & 66 to 89 & 177 \\
\hline $21-22(n=1926)$ & 68 & 46 to 96 & 32 & 69 & 52 to 88 & 61 & 75 & 63 to 87 & 153 & 75 & 43 to 123 & 16 & 73 & 63 to 83 & 214 \\
\hline $23-24(n=1103)$ & 47 & 25 to 81 & 13 & 66 & 45 to 92 & 34 & 91 & 75 to 110 & 108 & 57 & 23 to 117 & 7 & 83 & 70 to 98 & 142 \\
\hline $25-26(n=353)$ & 76 & 31 to 157 & 7 & 70 & 36 to 121 & 12 & 93 & 65 to 128 & 36 & 99 & 27 to 250 & 4 & 85 & 63 to 113 & 48 \\
\hline$\geqslant 27(n=100)$ & 76 & 9 to 278 & 2 & 122 & 45 to 267 & 6 & 100 & 50 to 179 & 11 & 87 & 2 to 464 & $i$ & 107 & 62 to 171 & 17 \\
\hline Total $(n=5585)$ & 63 & 51 to 78 & 88 & - 70 & 60 to 81 & 183 & 84 & 77 to 92 & 507 & 76 & 56 to 100 & 47 & 80 & 74 to 86 & 690 \\
\hline
\end{tabular}




\begin{tabular}{|c|c|c|c|c|c|c|c|c|c|c|c|c|c|c|c|}
\hline \multirow[b]{3}{*}{ Weight (pounds) } & \multicolumn{15}{|c|}{ Cause of death } \\
\hline & \multicolumn{3}{|c|}{ Coronary heart disease } & \multicolumn{3}{|c|}{ All cardiovascular disease } & \multicolumn{3}{|c|}{ All other causes } & \multicolumn{3}{|c|}{ Lung cancer } & \multicolumn{3}{|c|}{ All causes } \\
\hline & $\begin{array}{l}\text { Standardised } \\
\text { mortality } \\
\text { ratio }\end{array}$ & $\begin{array}{c}95 \% \\
\text { Confidence } \\
\text { interval }\end{array}$ & $\begin{array}{l}\text { No of } \\
\text { deaths }\end{array}$ & $\begin{array}{l}\text { Standardised } \\
\text { mortality } \\
\text { ratio }\end{array}$ & $\begin{array}{c}95 \% \\
\text { Confidence } \\
\text { interval }\end{array}$ & $\begin{array}{l}\text { No of } \\
\text { deaths }\end{array}$ & $\begin{array}{l}\text { Standardised } \\
\text { mortality } \\
\text { ratio }\end{array}$ & $\begin{array}{c}95 \% \\
\text { Confidence } \\
\text { interval }\end{array}$ & $\begin{array}{l}\text { No of } \\
\text { deaths }\end{array}$ & $\begin{array}{c}\text { Standardised } \\
\text { mortality } \\
\text { ratio }\end{array}$ & $\begin{array}{c}95 \% \\
\text { Confidence } \\
\text { interval }\end{array}$ & $\begin{array}{l}\text { No of } \\
\text { deaths }\end{array}$ & $\begin{array}{c}\text { Standardised } \\
\text { mortality } \\
\text { ratio }\end{array}$ & $\begin{array}{c}95 \% \\
\text { Confidence } \\
\text { interval }\end{array}$ & $\begin{array}{l}\text { No of } \\
\text { deaths }\end{array}$ \\
\hline \multicolumn{16}{|l|}{ At birth: } \\
\hline$\leqslant 5.5(n=458)$ & 102 & 76 to 134 & 51 & 96 & 74 to 122 & 65 & 90 & 70 to 115 & 67 & 116 & 70 to 181 & 19 & 93 & 78 to 110 & 132 \\
\hline $6-6 \cdot 5(n=1317)$ & 83 & 68 to 99 & 118 & 80 & 68 to 94 & 155 & 76 & 65 to 89 & 162 & 64 & 43 to 92 & 30 & 78 & 70 to 87 & 317 \\
\hline $7-7 \cdot 5(n=2991)$ & 82 & 72 to 92 & 266 & 80 & 72 to 89 & 353 & 79 & 72 to 88 & 383 & 75 & 59 to 93 & 80 & 80 & 74 to 86 & 736 \\
\hline $8-8 \cdot 5(n=3166)$ & 75 & 67 to 85 & 266 & 79 & 71 to 87 & 377 & 77 & 69 to 85 & 401 & 79 & 64 to 97 & 92 & 78 & 72 to 83 & 778 \\
\hline $9-9 \cdot 5(\mathrm{n}=1505)$ & 56 & 45 to 68 & 97 & 61 & 51 to 72 & 144 & 74 & 64 to 85 & 190 & 57 & 40 to 81 & 33 & 68 & 61 to 75 & 334 \\
\hline$\geqslant 10(n=704)$ & 66 & 50 to 86 & 55 & 69 & 54 to 86 & 78 & 79 & 64 to 96 & 97 & 94 & 61 to 138 & 26 & 74 & 63 to 86 & 175 \\
\hline \multicolumn{16}{|l|}{ At 1 year: } \\
\hline$\leqslant 18(n=559)$ & 105 & 82 to 133 & 68 & 101 & 81 to 124 & 89 & 77 & 61 to 97 & 74 & 98 & 61 to 149 & 21 & 89 & 76 to 103 & 163 \\
\hline $19-20(n=1702)$ & 83 & 71 to 97 & 158 & 84 & 73 to 96 & 217 & 92 & 82 to 104 & 261 & 89 & 67 to 115 & 56 & 88 & 81 to 97 & 478 \\
\hline $21-22(n=3288)$ & 85 & 76 to 95 & 305 & 86 & 78 to 95 & 420 & 78 & 71 to 86 & 415 & 73 & 58 to 90 & 86 & 82 & 77 to 88 & 835 \\
\hline $23-24(\mathrm{n}=2754)$ & 65 & 57 to 75 & 201 & 66 & 59 to 75 & 277 & 68 & 60 to 76 & 309 & 58 & 44 to 75 & 59 & 67 & 62 to 73 & 586 \\
\hline $25-26(n=1359)$ & 65 & 53 to 79 & 98 & 66 & 55 to 78 & 135 & 79 & 68 to 92 & 178 & 92 & 68 to 123 & 46 & 73 & 65 to 82 & 313 \\
\hline$\geqslant 27(n=479)$ & 42 & 26 to 63 & 23 & 46 & 32 to 64 & 34 & 77 & 59 to 99 & 63 & 66 & 34 to 115 & 12 & 62 & 50 to 76 & 97 \\
\hline Total $(n=10141)$ & 76 & 71 to 81 & 853 & 77 & 72 to 81 & 1172 & 78 & 74 to 82 & 1300 & 75 & 67 to 85 & 280 & 77 & 74 to 80 & 2472 \\
\hline
\end{tabular}

Among men (table II) standardised mortality ratios for cardiovascular disease fell with increasing birth weight $\left(\chi^{2}=8.5, p<0.005\right)$. The trend in death from coronary heart disease with birth weight was similar $\left(\chi^{2}=12.9, \mathrm{p}<0.0005\right)$. There was no trend in noncardiovascular causes of death or lung cancer. Standardised mortality ratios for all causes of death combined fell with increasing birth weight $\left(X^{2}=6 \cdot 9\right.$, $\mathrm{p}<0.01)$. There were strong trends in cardiovascular disease with weight at 1 year. Standardised mortality ratios fell with increasing weight at 1 year $\left(\chi^{2}=27 \cdot 5\right.$, $p<0.0001)$. The trend in death from coronary heart disease was similar $\left(\chi^{2}=23.8, \mathrm{p}<0.0001\right)$. There was no trend in non-cardiovascular causes of death but standardised mortality ratios for all causes fell with increasing weight at 1 year $\left(\chi^{2}=24.6, p<0.0001\right)$. There was no trend with lung cancer.

The cohort of men comprised 5654 men from the six districts analysed previously together with 4487 men from the other five districts. We compared the results of our first analysis with those for the additional men plus men in the original cohort who had died in the intervening period. The trends in cardiovascular disease, coronary heart disease, and all causes of death with birth weight and weight at 1 year were similar. For example, in the original analysis standardised mortality ratios for coronary heart disease in the six groups of weight at 1 year were $111,81,98,71,68,42$ $\left(\chi^{2}=11 \cdot 0, \mathrm{p}<0.002\right)$; in the additional data they were $98,85,74,60,62,41\left(\chi^{2}=12 \cdot 4, p<0 \cdot 0005\right)$.

In subsequent analyses we have used premature deaths - that is, death under the age of 65 yearsbecause of the greater accuracy of death certification

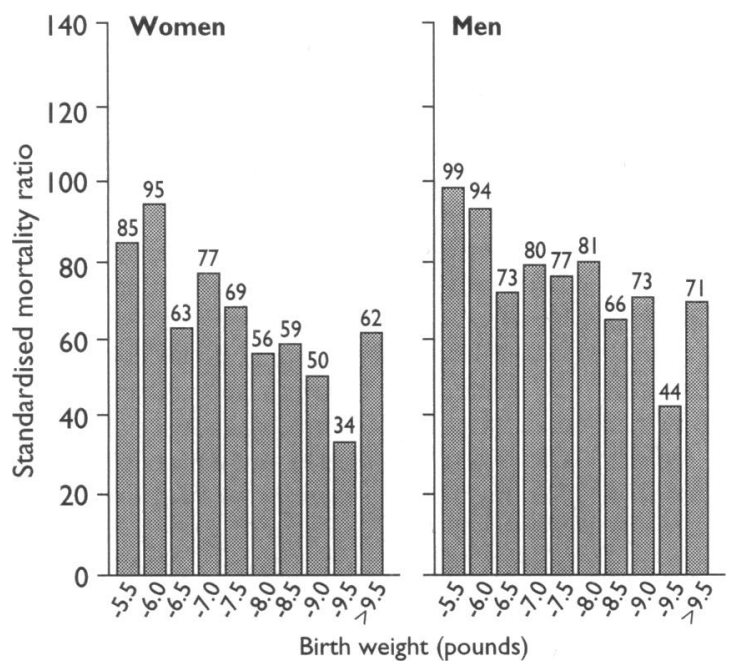

FIG 1-Standardised mortality ratios for cardiovascular disease below age of 65 according to birth weight

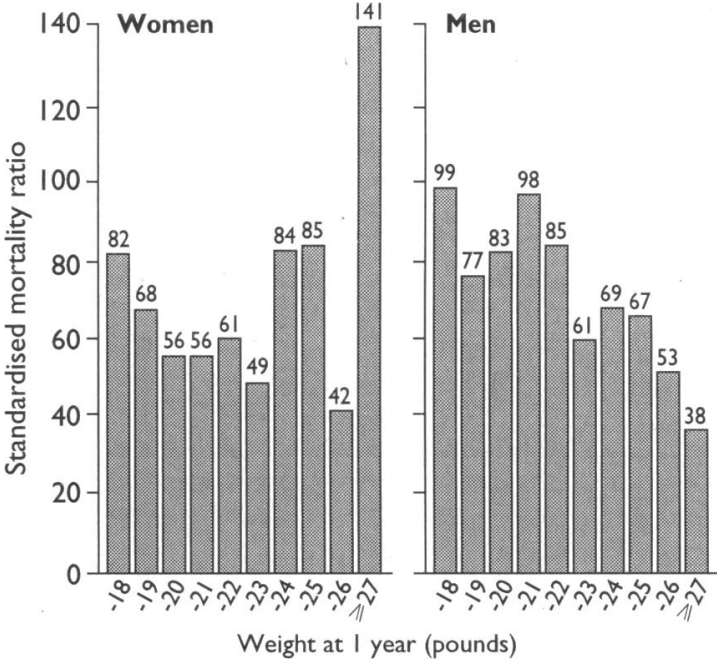

FIG 2-Standardised mortality ratios for cardiovascular disease below age of 65 according to weight at 1 year

and because we have shown that they are more strongly related to size at birth. ${ }^{2}$ There are no important differences in the trends in premature deaths and deaths at all ages. As in our previous analysis we also excluded from the data on weight at 1 year the $6 \%(361)$ of women and $7 \%$ (713) of men who were exclusively bottle fed. ${ }^{1}$ Their infant weight gain differed from that of the remainder, who were breast fed, in that they gained 0.6 pounds $(0.25 \mathrm{~kg})$ more between birth and 1 year. Figures 1 and 2 show the trends for premature death from cardiovascular disease among women and men in 10 groupings of birth weight and weight at 1 year. The trends with birth weight were similar in the two sexes. Rates of cardiovascular disease fell with increasing birth weight but increased slightly in the group over 9.5 pounds. The trends with weight at 1 year were different in the two sexes. The large, progressive fall in men contrasted with the absence of a trend in women.

Table III shows the simultaneous effects of birth weight and weight at 1 year on premature death from cardiovascular disease in the two sexes. Among women the combination of below average birth weight and above average weight at 1 year led to the highest death rates from cardiovascular disease. Among men, however, the combination of below average birth weight and below average weight at 1 year led to the highest death rates.

Table IV shows premature death rates from cardiovascular disease according to the method of infant feeding. Two per cent of the women (109) and 3\% of the men (323) could not be classified. Men who were 
TABLE II-Standardised mortality ratios for cardiovascular disease below 65 years according to birth weight and weight at 1 year. Numbers of deaths are given in parentheses

\begin{tabular}{|c|c|c|c|c|}
\hline \multirow{2}{*}{$\begin{array}{l}\text { Birth weight } \\
\text { (pounds) }\end{array}$} & \multicolumn{4}{|c|}{ Weight at 1 year (pounds) } \\
\hline & $\leqslant 21$ & $22-23$ & $\geqslant 24$ & Total \\
\hline Women & $63(74)$ & $56(33)$ & $84(27)$ & $65(134)$ \\
\hline $\begin{array}{l}\leqslant 7 \\
7 \cdot 5-8 \cdot 5 \\
\geqslant 9\end{array}$ & $\begin{array}{l}68(41) \\
63(30) \\
36(3)\end{array}$ & $\begin{array}{l}81(16) \\
51(15) \\
20(2)\end{array}$ & $\begin{array}{l}88(7) \\
78(12) \\
92(8)\end{array}$ & $\begin{array}{l}73(64) \\
62(57) \\
48(13)\end{array}$ \\
\hline $\begin{array}{l}\text { Men } \\
\quad \leqslant 7 \\
7 \cdot 5-8 \cdot 5 \\
\geqslant 9\end{array}$ & $\begin{array}{l}\quad 90(344) \\
97(170) \\
89(138) \\
73(36)\end{array}$ & $\begin{array}{l}81(76) \\
71(122) \\
73(53)\end{array}$ & $\begin{array}{l}62(39) \\
62(191) \\
63(90) \\
57(62)\end{array}$ & $\begin{array}{l}\quad 76(786) \\
86(285) \\
75(350) \\
66(151)\end{array}$ \\
\hline
\end{tabular}

TABLE IV-Standardised mortality ratios from cardiovascular disease below 65 years according to method of infant feeding

\begin{tabular}{|c|c|c|c|c|c|c|}
\hline & \multicolumn{3}{|c|}{ Women } & \multicolumn{3}{|c|}{ Men } \\
\hline & $\begin{array}{c}\text { Standardised } \\
\text { mortality } \\
\text { ratio }\end{array}$ & $\begin{array}{l}\text { No of } \\
\text { deaths }\end{array}$ & $\begin{array}{c}95 \% \\
\begin{array}{c}\text { Confidence } \\
\text { interval }\end{array}\end{array}$ & $\begin{array}{c}\text { Standardised } \\
\text { mortality } \\
\text { ratio }\end{array}$ & $\begin{array}{l}\text { No of } \\
\text { deaths }\end{array}$ & $\begin{array}{c}95 \% \\
\text { Confidence } \\
\text { interval }\end{array}$ \\
\hline $\begin{array}{l}\text { Breast and bottle fed } \\
\text { Breast fed, weaned at } 1 \text { year } \\
\text { Breast fed, not weaned at } 1 \text { year } \\
\text { Bottle fed }\end{array}$ & $\begin{array}{r}65 \\
65 \\
63 \\
108\end{array}$ & $\begin{array}{l}40 \\
73 \\
20 \\
15\end{array}$ & $\begin{array}{l}47 \text { to } 89 \\
51 \text { to } 82 \\
39 \text { to } 98 \\
60 \text { to } 178\end{array}$ & $\begin{array}{l}73 \\
72 \\
93 \\
81\end{array}$ & $\begin{array}{r}213 \\
377 \\
181 \\
64\end{array}$ & $\begin{array}{l}63 \text { to } 82 \\
64 \text { to } 79 \\
80 \text { to } 107 \\
62 \text { to } 103\end{array}$ \\
\hline
\end{tabular}

TABLE V-Mean birth weight and weight at 1 year according to social class

\begin{tabular}{lcccccccc}
\hline & \multicolumn{2}{c}{ No of subjects } & & \multicolumn{2}{c}{ Mean birth weight (pounds) } & & \multicolumn{2}{c}{ Mean weight at 1 year (pounds) } \\
\cline { 2 - 3 } Social class & Women & Men & & Women & Men & & Women & Men \\
\hline I & 27 & 96 & & 7.5 & 7.7 & & 21.0 & 22.2 \\
II & 106 & 372 & & 7.5 & 7.9 & & 21.6 & 22.5 \\
III non-manual & 96 & 279 & & 7.3 & 7.8 & & 21.3 & 22.4 \\
III manual & 194 & 920 & & 7.5 & 7.9 & & 21.3 & 22.2 \\
IV & 148 & 512 & & 7.4 & 7.7 & & 21.2 & 22.1 \\
V & 46 & 228 & & 7.6 & 7.8 & & 21.3 & 21.7 \\
\hline Total & 617 & 2407 & 7.5 (SD 1.2) & 7.8 (SD 1.3) & 21.3 (SD 2.5) & 22.2 (SD 2.6) \\
\hline
\end{tabular}

breast fed beyond 1 year had raised death rates from cardiovascular disease. There was no similar effect in women. In our original analysis we showed that standardised mortality ratios for coronary heart disease at all ages were 97 among men breast fed beyond 1 year compared with 79 among men who were weaned before 1 year. ${ }^{6}$ The corresponding figures for the additional data in this analysis are 73 compared with 66 . Women and men who were exclusively bottle fed from birth had raised cardiovascular death rates, though this was not significant (table IV)

Among the people who died, mean birth weight was not related to social class at death (table V). There was no trend in mean weight at 1 year with social class, although the weight of men in social class $\mathrm{V}$ was below the average.

\section{Discussion}

This study provides the first evidence that early growth may be linked to death from cardiovascular disease among women. It also replicates our original observations among men. ${ }^{1}$ Death rates from cardiovascular disease among women and men fell progressively between those with low and high birth weights. There was a small increase in mortality at birth weights above 9.5 pounds $(4.3 \mathrm{~kg})$. This could be associated with maternal diabetes, though we have no evidence of this. Cardiovascular death rates were not related to weight at 1 year in women but in men death rates fell progressively with increasing weight. The trend in men was strong and was reflected in a fall in mortality from all causes. Among women the highest cardiovascular disease death rates were in those with below average birth weight but above average weight at 1 year. Among men the highest rates were in those with below average birth weight and below average weight at 1 year.
Breast feeding for more than one year increased the risk of cardiovascular disease in men but not women. We have previously shown that prolonged breast feeding is associated with raised serum low density lipoprotein concentrations in men. ${ }^{6}$ The ruasons for this are unclear. One possible explanation, which derives from observations on baboons, is that thyroid hormones present in breast milk may down regulate the suckling infant's thyroid function in later life and thereby influence cholesterol metabolism. ${ }^{78}$ We cannot explain the absence of an association between prolonged breast feeding and cardiovascular disease in women.

We traced men born from 1911 onwards, when the health visitor records were established. Many women born before 1923 could not be traced because their married name was unknown. The cohort of women was therefore smaller and younger which, together with their lower mortality, reduced the power of the study to detect differences in cardiovascular death rates among women.

We included only people who had both birth weight and weight at 1 year recorded. We traced $79 \%$ of the men and $60 \%$ of the women. The mean birth weight and weight at 1 year of men who were not traced were similar to those of men who were traced. The mean weights of women in the two categories were identical This shows that selection processes which determine tracing are only weakly related to early weight. By contrast, the processes which determine migration away from place of birth are related to birth weight and thereby confound migrant studies. ${ }^{9}$ Our analysis was based on internal comparisons and selection of subjects with complete records. Failure to trace some subjects would introduce bias only if the relation between early growth and cardiovascular disease differed in those included and excluded and those traced and not traced. This seems unlikely.

\section{ARGUMENTS FOR PROGRAMMING EFFECT}

People who had reduced growth in utero and during infancy may continue to be exposed to an adverse environment in childhood and adult life, and it has been suggested that it is the later environment which produces the effects we attribute to programming. We think that there are five reasons why this argument cannot be sustained.

Firstly, associations between early growth and cardiovascular risk factors are being found in different populations. The association between low birth weight and impaired glucose tolerance in adults, for example, has been shown in three studies in Britain ${ }^{10-12}$ and two studies in the United States. ${ }^{13} 14$ The association with raised blood pressure has been shown in four studies of adults (C N Martyn, unpublished data) $)^{315}$ and is consistently found in children. Blood pressure is known to "track" from childhood to adult life. Tracking is perturbed, however, during adolescence, which may explain why two studies have shown only weak associations between birth weight and blood pressure in teenagers. ${ }^{1617} \mathrm{~A}$ study of people of different ages suggests that raised blood pressure is initiated in utero and thereafter amplified with increasing age. ${ }^{15}$

Secondly, in our studies of impaired glucose tolerance and blood pressure and of the link between infant growth and plasma fibrinogen and serum cholesterol concentrations, ${ }^{61819}$ we have shown that the associations are independent of social class at birth, social class as an adult, cigarette smoking, alcohol consumption, and obesity. Adult lifestyle influences, however, add to the effects of early life. For example, the prevalence of impaired glucose tolerance was highest in people who had low birth weight but became obese as adults. ${ }^{10}$

Thirdly, in studies of survivors in the Hertfordshire 
cohort we have shown that birth weight is unrelated to social class either at birth or currently. ${ }^{3}$ In this study we have information on social class for people who died. Among them birth weight was similarly unrelated to social class (table V). Although average weight at 1 year was lower in men in social class $\mathrm{V}$, the difference was small and there was no downward trend through the social classes.

Fourthly, the association between early weight and cardiovascular disease is specific. In neither women nor men were birth weight or weight at 1 year associated with death from lung cancer, which serves as an indicator of cigarette smoking; nor were they associated with deaths from non-cardiovascular causes.

Fifthly, the associations are strong and graded. In particular the association between cardiovascular death in men and weight at 1 year is highly significant. Body weight at birth is only a proxy for the changes in the body's structure, physiology, and metabolism that have been programmed in utero, yet the relative risks associated with low birth weight are large: the risk of syndrome $\mathrm{X}$, for example, is 10 times higher among men whose birth weight was 6.5 pounds $(2.95 \mathrm{~kg})$ or less than in men whose birth weight was more than $9 \cdot 5$ pounds $(4 \cdot 31 \mathrm{~kg}){ }^{20}$

For these reasons we conclude that reduced early growth and cardiovascular disease are causally linked. This conclusion is strengthened by recent animal studies which show that experimentally induced low birth weight is followed by persistent raised blood pressure. $^{21-23}$

\section{WORKING HYPOTHESIS}

Our working hypothesis is that fetal undernutrition is associated with changes in the concentration of fetal and placental hormones. ${ }^{4}$ Persisting changes in the levels of hormone secretion, or in the sensitivity of tissues to them, may link fetal undernutrition with abnormal structure, function, and disease in adult life. ${ }^{24}$

Insulin has a central role in regulating fetal growth. It ensures that fetal growth rates are commensurate with the nutrient supply. ${ }^{25}$ Babies who are small for dates have disturbed glucose-insulin metabolism. This manifests in adult life as a high prevalence of noninsulin dependent diabetes, which is a risk factor for cardiovascular disease. ${ }^{1011}$ This is found in both women and men. ${ }^{11}$ The association between lower birth weight and raised death rates from cardiovascular disease in women and men may therefore reflect persisting changes in secretion of insulin or in the sensitivity of tissues to it. Babies with lower birth weight who are thin are insulin resistant as adults. ${ }^{2026}$ Thin babies tend to catch up in weight after birth..$^{27} 28$

In late gestation and during infancy, growth hormone and insulin-like growth factor I, which mediates some of the effects of growth hormone, become increasingly important for the control of growth. ${ }^{29}$ Babies with low weight gain in infancy may be deficient in growth hormone or resistant to it. ${ }^{4} \mathrm{At}$ birth these babies may already be short, though of average weight. ${ }^{20}$ As adults babies with low weight gain have raised serum cholesterol and plasma fibrinogen concentrations. ${ }^{1819}$ The raised cardiovascular death rates among men with lower weight at 1 year may be the result of persisting disturbance of growth hormone metabolism. We suggest that boys are more vulnerable to disturbance of growth hormone metabolism because of their more rapid growth trajectory in utero. ${ }^{3031}$ Among animals undernutrition in utero has a greater effect on the development of fetuses which are growing rapidly. ${ }^{32} 33$

Our hypothesis is that whereas both girls and boys may develop persisting changes in insulin metabolism through undernutrition in utero, boys are more prone

\section{Epidemiological implications}

- Previous studies have suggested that cardiovascular disease in adult men is linked to in utero development

- In this study low birth weight is linked to cardiovascular disease in both women and men

- Low weight gain in infancy is linked to cardiovascular disease only in men

- This is further evidence that cardiovascular disease is programmed in response to undernutrition in early life

to develop changes in growth hormone metabolism. This hypothesis provides a framework within which the lower rates of cardiovascular disease in women than in men can be explored.

We thank Hertfordshire County Archives, and the Hertfordshire health authorities who preserved the records and allowed us to use them, and the staff at the NHS central registry, Southport, and Office of Population Censuses and Surveys, London, who traced the men and women. Brian Pannett and Jackie Ariouat carried out the national search which led to the discovery of these data.

1 Barker DJP, Winter PD, Osmond C, Margetts B, Simmonds SJ. Weight in infancy and death from ischaemic heart disease. Lancet 1989;ii:577-80.

2 Barker DJP, Osmond C, Simmonds SJ, Wield GA. The relation of small head circumference and thinness at birth to death from cardiovascular disease in circumference and thinness at
adult life. $B M \mathcal{F} 1993 ; 306: 422-6$.

3 Barker DJP, ed. Fetal and infant origins of adult disease. London: BMJ Publishing Group, 1992.

4 Barker DJP, Gluckman PD, Godfrey KM, Harding JE, Owens JA, Robinson JS. Fetal nutrition and cardiovascular disease in adult life. Lancet 1993;341: 938-41.

5 Berry G. The analysis of mortality by the subject-years method. Biometrics 1983;39:173-84.

6 Fall CHD, Barker DJP, Osmond C, Winter PD, Clark PMS, Hales CN. Relation of infant feeding to adult serum cholesterol concentration and death from ischaemic heart disease. $B M \mathcal{F}$ 1992;304:801-5.

7 Lewis DS, McMahan CA, Mott GE. Nursery rearing and formula feeding affect plasma thyroid hormone concentrations in infant baboons. Biol

Neonate (in press).
8 Phillips DIW, Barker DJP, Osmond C. Infant feeding, fetal growth and adult thyroid function. Acta Endocrinol 1993;129:134-8.

9 Martyn CN, Barker DJP, Osmond C. Selective migration by birthweight. I Epidemiol Community Health 1993;47:76.

10 Hales CN, Barker DJP, Clark PMS, Cox LJ, Fall C, Osmond C, et al. Fetal and infant growth and impaired glucose tolerance at age 64. $B M f$ 1991;303:1019-22.

11 Phipps K, Barker DJP, Hales CN, Fall CHD, Osmond C, Clark PMS. Fetal growth and impaired glucose tolerance in men and women. Diabetologia 1993;36:225-8.

12 Robinson S, Walton RJ, Clark PM, Barker DJP, Hales CN, Osmond C. The relation of fetal growth to plasma glucose in young men. Diabetologia 1992;35:444-6.

13 Athens $M$, Valdez R, Stern $M$. Effect of birthweight on future development of 'syndrome X' in adult life. Diabetes 1993;42(suppl 1):A61.

14 McCance DR, Pertitt DJ, Hanson RL, Jacobsson LTH, Knowler WC, Bennett PH. Low birthweight and type II diabetes in Pima Indians. Diabetologia 1993;36:(suppl 1):A4

15 Law CM, de Swiet M, Osmond C, Fayers PM, Barker DJP, Cruddas AM, et al. Initiation of hypertension in utero and its amplification throughout life. BMF 1993;306:24-7.

16 Seidman DS, Laor A, Gale R, Stevenson DK, Mashiach S, Danon YL. Birth weight, current body weight and blood pressure in late adolescence. BMF 1991;302:1235-7.

17 Williams S, St George IM, Silva PA. Intrauterine growth retardation and blood pressure at age seven and eighteen. $\mathcal{F}$ Clin Epidemiol 1992;45:1257-73.

18 Barker DJP, Meade TW, Fall CHD, Lee A, Osmond C, Phipps K, et al. Relation of fetal and infant growth to plasma fibrinogen and factor VII concentrations in adult life. BMF 1992;304:148-52.

19 Barker DJP, Martyn CN, Osmond C, Hales CN, Fall CHD. Growth in utero and serum cholesterol concentrations in adult life. BMF 1993;307:1524-7.

20 Barker DJP, Hales CN, Fall CHD, Osmond C, Phipps K, Clark PMS. Type 2 (non-insulin dependent) diabetes mellitus, hypertension and hyperlipidaemia (syndrome $\mathrm{X}$ ): relation to reduced fetal growth. Diabetologia 1993;36:62-7.

21 Persson E, Jansson $\mathrm{T}$. Low birthweight is associated with elevated adult blood pressure in the chronically catheterised guinea-pig. Acta Physiol Scand 1992;145:195-6.

22 Edwards CRW, Benediktsson R, Lindsay RS, Seckl JR. Dysfunction of placental glucocorticoid barrier: link between fetal environment and adult hypertension. Lancet 1993;341:355-7.

23 Langley SC, Jackson AJ. Increased systolic pressure in adult rats induced by fetal exposure to maternal low protein diets. Clinical Science (in press).

24 Hales CN, Barker DJP. Type 2 (non-insulin-dependent) diabetes mellitus: the thrifty phenotype hypothesis. Diabetologia 1993;35:595-601.

25 Fowden AL. The role of insulin in prenatal growth. $f$ Dev Physiol 1989;12: 173-82. 
26 Phillips DIW, Barker DJP, Hales CN, Hirst S, Osmond C. Thinness at birth and insulin resistance in adult life. Diabetologia (in press).

27 Holmes GE, Miller HC, Hassanein K, Lansky SB, Goggin JE. Postnata somatic growth in infants with atypical fetal growth patterns. Am f Dis Child 1977;3:1078-83.

28 Villar J, Smeriglio V, Martorell R, Brown CH, Klein RE. Heterogeneous growth and mental development of intrauterine growth retarded infants growth and mental development of intrauterine growth

29 Gluckman PD, Gunn AJ, Wray A, Cutfield W, Chatelin PG, Guilbaud O, et al.

Congenital idiopathic growth hormone deficiency is associated with prenatal and early postnatal growth failure. $\mathcal{F}$ Pediatr 1992;121:920-3.
30 Burgoyne PS. A Y-chromosomal effect on blastocyst cell numbers in mice. Development 1993;117:341-5.

31 Pedersen JF. Ultrasound evidence of sexual difference in fetal size in first trimester. $B M f 1980 ; 281: 1253$

32 Harding JE, Liu L, Evans PC, Oliver M, Gluckman PD. Intrauterine feeding of the growth retarded fetus: can we help? Early Hum Dev 1992-29:193-7.

33 Widdowson EM, McCance RA. The effect of finite periods of undernutivion Widdowson EM, McCance RA. The effect of finite periods of undernutrition at different ages on the composition and subsequent development of the rat.
Proc R Soc Lond [Biol] 1963;158:329-42.

(Accepted 15 November 1993)

\title{
Growth in utero and serum cholesterol concentrations in adult life
}

\author{
D J P Barker, C N Martyn, C Osmond, C N Hales, C H D Fall
}

\begin{abstract}
Objective-To see whether reduced rates of fetal growth are related to raised serum cholesterol concentrations in adult life.

Design-Follow up study of men and women whose size at birth had been recorded.

Setting-Jessop and Northern General Hospitals, Sheffield.

Subjects-219 men and women born in the Jessop Hospital during 1939-40.
\end{abstract}

Main outcome measures-Serum concentrations of total cholesterol, low density lipoprotein cholesterol, and apolipoprotein $B$.

Results-Men and women who had had a small abdominal circumference at birth had raised serum concentrations of total and low density lipoprotein cholesterol and apolipoprotein B. This was independent of the duration of gestation. Serum concentrations of total cholesterol fell by $0.25 \mathrm{mmol} / \mathrm{A}$ $(95 \%$ confidence interval 0.09 to 0.42$)$ with each 1 in $(2.54 \mathrm{~cm})$ increase in abdominal circumference. The corresponding figure for serum low density lipoprotein cholesterol was $0.26 \mathrm{mmol} / \mathrm{l}(0.11$ to 0.42$)$ and for serum apolipoprotein $\mathrm{B} 0.04 \mathrm{~g} / \mathrm{l}(0.02$ to 0.07$)$. Small head and chest circumferences at birth and short length were each associated with raised serum low density lipoprotein cholesterol concentrations but the trends disappeared in a simultaneous regression with abdominal circumference at birth. The association between abdominal circumference at birth and low density lipoprotein cholesterol concentration was independent of social class, current body weight, cigarette smoking, and alcohol consumption.

Conclusion-Raised serum cholesterol concentrations in adult life are associated with impaired growth during late gestation, when fetal undernutrition has a disproportionate effect on liver growth. Impaired liver growth may permanently alter low density lipoprotein cholesterol metabolism.

\section{Introduction}

The reasons why serum cholesterol concentrations differ widely within and between populations are not understood. They are important because cholesterol may be directly concerned in the pathogenesis of atheroma and is strongly associated with the risk of coronary heart disease. ${ }^{12}$

Experiments show that changing the diets of pregnant animals or their newborn offspring may permanently change the rate of cholesterol synthesis and excretion. ${ }^{3}$ Permanent changes in cholesterol metabolism may also be induced by cholestyramine given to mothers or neonates. ${ }^{45}$ Rats that are weaned prematurely have a raised serum cholesterol concentration in later life, which becomes apparent only after seven months, ${ }^{6}$ while breast fed baboons have higher ratios of serum low density to high density lipoprotein cholesterol concentrations in adult life than those fed on infant formulas. ${ }^{7}$ These observations suggest that the activity of enzymes controlling cholesterol synthesis and excretion may be programmed by nutrition during early development.

In humans there is limited evidence that nutrition before and immediately after birth influences lipid metabolism throughout life. In a study of men aged 59-70 who were born in Hertfordshire and whose birth weight, infant growth, and feeding were recorded, those who were heavier at birth were found to have lower serum concentrations of apolipoprotein B-the structural apolipoprotein linked to low density lipoprotein. ${ }^{8}$ Those who had been breast fed beyond 1 year of age or who had been exclusively bottle fed had higher serum concentrations of total and low density lipoprotein cholesterol and apolipoprotein B. These patterns of feeding were also associated with raised death rates from coronary heart disease.

The findings in Hertfordshire are part of a growing body of evidence that the metabolic abnormalities which lead to coronary heart disease are programmed by nutrition in utero and during infancy. Studies show that men and women who had low growth rates in utero or in the first year after birth now have raised blood pressure, ${ }^{9}$ impaired glucose tolerance, ${ }^{10}$ abnormal blood coagulation, ${ }^{11}$ and raised death rates from coronary heart disease..$^{12}$ These associations are strong, graded, and independent of social class, smoking, and other aspects of adult lifestyle.

We measured serum lipid concentrations in a group of middle aged men and women who were born in a maternity hospital in Sheffield during 1939-40. Our aim was to see whether retarded growth in utero led to the pattern of serum lipid concentrations that is associated with increased risk of coronary heart disease. Retarded intrauterine growth affects body proportions at birth as well as body size, and these particular men and women were studied because their birth records included not only birth weight but also length at birth and circumferences of the head, chest, and abdomen. Abdominal circumference seemed particularly important because it reflects the size of the liver, which has a central role in cholesterol synthesis and excretion.

\section{Subjects and methods}

A standardised record form was kept for each woman admitted to the Jessop Maternity Hospital in Sheffield..$^{13}$ Records included the date of the mother's last menstrual period, details of previous pregnancies, and measurement of the external conjugate diameter of the pelvis-the distance between the symphysis pubis and the fifth lumbar vertebra. Birth weight was recorded in pounds and grams $(1 \mathrm{lb}=454 \mathrm{~g})$. Placental weight was recorded in grams. Head, chest, and abdominal circumferences and crown-heel length were recorded in inches $(1 \mathrm{in}=2.54 \mathrm{~cm})$. 